\title{
TINGKAT LITERASI MEMBACA PESERTA DIDIK KELAS IV \\ DI SD MUHAMMADIYAH BANTUL KOTA
}

\author{
Ika Nur Harini
}

\author{
Sekolah Dasar Islam Terpadu Ar-Raihan, Bantul \\ Email: ikhanurharini@gmail.com
}

\begin{abstract}
ABSTRAK
Penelitian ini bertujuan untuk mengetahui tingkat literasi membaca peserta didik kelas IV SD Muhammadiyah Bantul Kota. Penelitian kuantitatif noneksperimen dengan metode kuantitatif deskripstif dilaksanakan di kelas IV SD Muhammadiyah Bantul Kota dengan penentuan sampel menggunkan teknik random sampling sehingga diperoleh kelas IV A sebagai sampel. Instrumen tes yang digunakan adalah tes PIRLS Framework yang bersifat internasional dan tes buatan penulis serta angket. Hasil penelitian menunjukkan bahwa tingkat literasi membaca dari aspek tujuan membaca dan proses pemahaman terbagi menjadi 5 kriteria, yaitu terdapat 10 peserta didik yang memperoleh kriteria $\mathrm{A}$, 10 peserta didik dengan kriteria $\mathrm{B}, 3$ peserta didik dengan kriteria $\mathrm{C}$, 3 peserta didik dengan Kriteria $\mathrm{D}$, dan 5 peserta didik dengan kriteria E. Kemudian untuk rata-rata persentasenya adalah 67 dengan kriteria $B$ yaitu tinggi.
\end{abstract}

Kata kunci: Tingkat Literasi Membaca, Sekolah Dasar.

\section{ABSTRACT}

This study is aimed to determine the level of students reading literacy class IV SD Muhammadiyah Bantul Kota. Quantitative non-experimental research using descriptive quantitative method is carried out in class IV of SD Muhammadiyah Bantul Kota with sample determination used random sampling technique which obtained class IV A as sample. Test instruments used are PIRLS Framework test that is International, author's 
test, and questionnaire. The results showed that the level of reading literacy from reading objectives and comprehension process are divided into 5 criteria, there are 10 students who get criterion A, 10 students with criterion $B, 3$ students with criterion $C, 3$ students with criterion $D$, and 5 students with criterion $E$. Then for the average percentage is 67 with criterion $B$ that is high.

\section{Keywords: Level Reading Literacy, Elementary School.}

\section{A. PENDAHULUAN}

Menurut hasil penelitian Programme for International Student Assessment (PISA) menyebutkan bahwa budaya literasi masyarakat Indonesia pada tahun 2012 terburuk kedua dari 65 negara yang diteliti di dunia. Indonesia menempati urutan ke 64 dari 65 negara tersebut. ${ }^{1}$ Berdasarkan studi "Most Littered Nation In the World" yang dilakukan oleh Central Connecticut State Univesity pada Maret 2016 lalu, Indonesia dinyatakan menduduki peringkat ke-60 dari 61 negara soal minat membaca. Indonesia persis berada di bawah Thailand (59) dan di atas Bostwana (61). Padahal, dari segi penilaian infrastuktur untuk mendukung membaca peringkat Indonesia berada di atas negara-negara Eropa. ${ }^{2}$

Dari beberapa hasil survei yang telah disebutkan di atas, dapat dilihat bahwa minat baca masyarakat Indonesia khususnya para peserta didik memang masih rendah. Banyak aspek yang menyebabkan rendahnya minat baca di Indonesia adalah lingkungan keluarga dan sekitar yang kurang mendukung kebiasaan membaca, rendahnya daya beli buku masyarakat berkaitan dengan tingkat ekonomi dan rendahnya kesadaran pentingnya buku, minimnya jumlah perpustakaan yang memadai, dampak negatif media elektronik, model pembelajaran secara umum belum membuat peserta didik harus membaca dan sistem pembelajaran membaca yang belum tepat. ${ }^{3}$

1. Andi Nur Aminah (Ed.), "Literasi Indonesia Sangat Rendah," Republika Online, 15 Desember 2014, https://republika.co.id/berita/koran/didaktika/14/12/15/ngm3g840literasi-indonesia-sangat-rendah.

2. Mikhael Gewati, "Minat Baca Indonesia Ada di Urutan ke-60 Dunia," KOMPAS.com, 29 Agustus 2016, https://edukasi.kompas.com/read/2016/08/29/07175131/minat.baca. indonesia.ada.di.urutan.ke-60.dunia.

3. Sri Wahyuni, "MENUMBUHKEMBANGKAN MINAT BACA MENUJU MASYARAKAT LITERAT,” Diksi 16, no. 2 (2009), https://journal.uny.ac.id/index.php/ diksi/article/view/6617. 
Berbeda dengan tingkat internasional, di Indonesia sesuai data Badan Pusat Statistik (BPS), ada tiga daerah yang minat baca pelajarnya cukup tinggi. Salah satunya adalah Daerah Istimewa Yogyakarta. Data dari BPS mencatat, persentase peserta didik yang membaca buku di DIY mencapai 91,00 persen atau berada di urutan keempat. Minat baca siswa bisa dilihat dari jenis bacaan yang dibaca, seperti surat kabar atau majalah, membaca artikel elektronik, buku pelajaran dan buku non pelajaran. ${ }^{4}$

Bantul merupakan salah satu kabupaten di Daerah Istimewa Yogyakarta. Melalui Dinas Perpustakaan dan Kearsipan Kabupaten Bantul, yang membuat terobosan untuk mendongkrak minat baca masyarakat melalui pameran buku kerjasama Diva Press dengan Dinas Perpustakaan dan Kearsipan Bantul. Bahkan gerakan budaya membaca juga tumbuh dan berkembang dengan melakukan pembinaan ke sejumlah perpustakaan desa di Bantul. Kebijakan itu merupakan strategi dalam pengembangan perpustakaan desa. ${ }^{5}$ Merujuk pada salah satu kecamatan di Kabupaten Bantul yaitu Kecamatan Bantul Kota. Di kecamatan tersebut terdapat 27 sekolah setingkat SD baik sekolah negeri maupun swasta. Pada tahun ajaran 2016/2017 ini pemerintah membuat program Gerakan Literasi Sekolah (GLS) yaitu kegiatan membaca buku non pelajaran sebelum kegiatan belajar mengajar selama 15 menit di kelas atau di lingkungan sekolah.

Salah satu sekolah yang telah melaksanakan program GLS adalah SD Muhammadiyah Bantul Kota. Sekolah ini merupakan salah satu sekolah favorit di Kabupaten Bantul. Pada tahun ajaran 2016/2017 ini jumlah peserta didiknya mencapai 700 peserta didik, dimana terbagi menjadi 22 rombel kelas. Untuk mendukung program tersebut di setiap kelas terdapat pojok baca, rata-rata setiap kelas terdapat 20-30 buah buku. Buku yang disediakan adalah kumpulan buku dari semua peserta didik di kelas tersebut yang dikoordinir langsung oleh wali kelas. Selain itu kondisi perpustakaan sekolah juga mendukung, jumlah buku yang tersedia cukup banyak yaitu 1.812 judul buku dan dengan jumlah buku yaitu 4.763 buah. Selain itu setiap bulannya juga terdapat jadwal bergilir untuk pelaksanaan program GLS di perpustakaan sekolah selama 20 menit. Beberapa kegiatan yang ada di

4. Jurnalis Okezone, "Pelajar di DIY Memiliki Minat Baca Tinggi: Okezone News," https://news.okezone.com/, diakses 1 Agustus 2018, https://news.okezone.com/ $\mathrm{read} / 2016 / 09 / 03 / 65 / 1480357 /$ pelajar-di-diy-memiliki-minat-baca-tinggi.

5. Admin MEPNews, "Bantul Cerdas, Tapi Minat Baca Minim," MEPNEWS.ID, 9 Maret 2017, http://mepnews.id/2017/03/09/bantul-cerdas-tapi-minat-baca-minim/. 
perpustakaan tersebut adalah menonton film, mendengarkan teman yang sedang bercerita, mendongeng dan lain-lain, kegiatan ini dikoordinir oleh pustakawan. ${ }^{6}$

\section{B. METODE PENELITIAN}

Penelitian ini termasuk penelitian kuantitatif noneksperimental dengan metode deskriptif. Populasi dalam penelitian ini adalah peserta didik kelas IV di SD Muhammadiyah Bantul Kota, yang terdiri kelas IV A, IV B, IV C dan IV D. Pemilihan sampel dalam penelitian ini dengan menggunakan teknik random sampling sehingga diperoleh sampel kelas IV A. Instrumen yang digunakan pada penelitian ini sebagai alat pengumpul data adalah tes, angket, dan dokumentasi. Peneliti menggunakan instrumen tes dan angket dari PIRLS Framework dan dari peneliti. Tes yang digunakan untuk mengetahui kemampuan membaca dalam proses pemahaman dan tujuan membaca peserta didik. Jumlah soal yang diujikan terdiri dari 30 soal tes membaca Tahapan dalam analisis data menggunakan reduksi data, penyajian data dan verifikasi.

\section{HASIL PENELITIAN DAN PEMBAHASAN}

Tes membaca ini dilakukan melalui dua tahap yaitu melakukan tes membaca dan pengisian angket. Pertama, seluruh peserta didik kelas IV A mempersiapkan diri dan mengerjakan soal tes membaca yang telah dibagikan dalam waktu 45 menit. Kemudian diberikan waktu istirahat 5 menit dan dilanjutkan pengisian angket selama 15 menit.

Setelah dilakukan penelitian, dari 30 soal tes membaca kemudian dilakukan validasi empiris yang menggunakan IBM SPSS Statistics 22.

6. Wahyu Widayanti, Wawancara dengan Pustakawan di Ruang Perpustakaan SD Muhammadiyah Bantul Kota, Agustus 2017. 


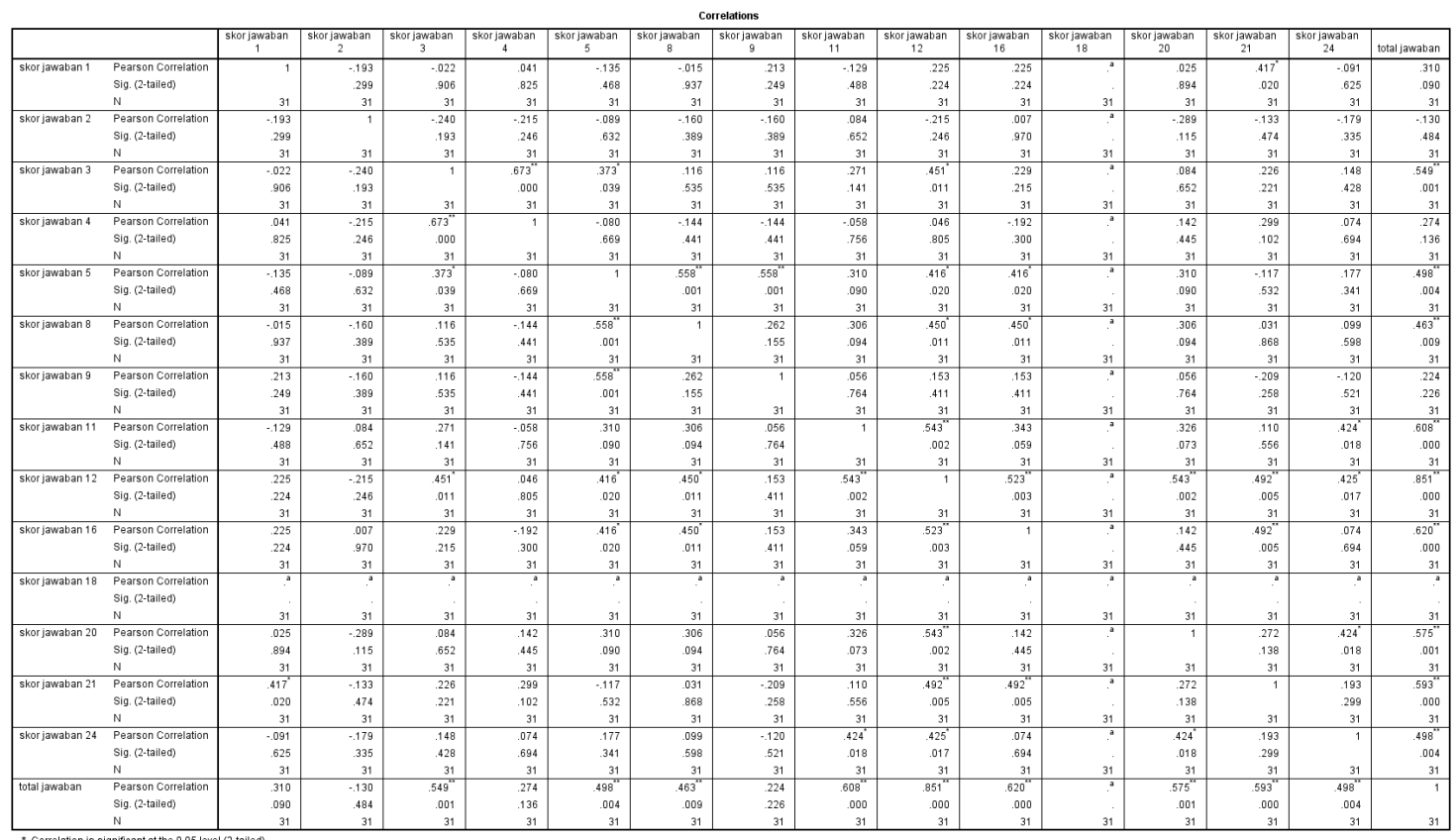

- Correlation is significant at the 0.05 level (2-ailed.
*. Correlation is significant at the 0.01 level (2-taled)

Gambar 1. Korelasi Product Moment Aspek Tujuan Membaca

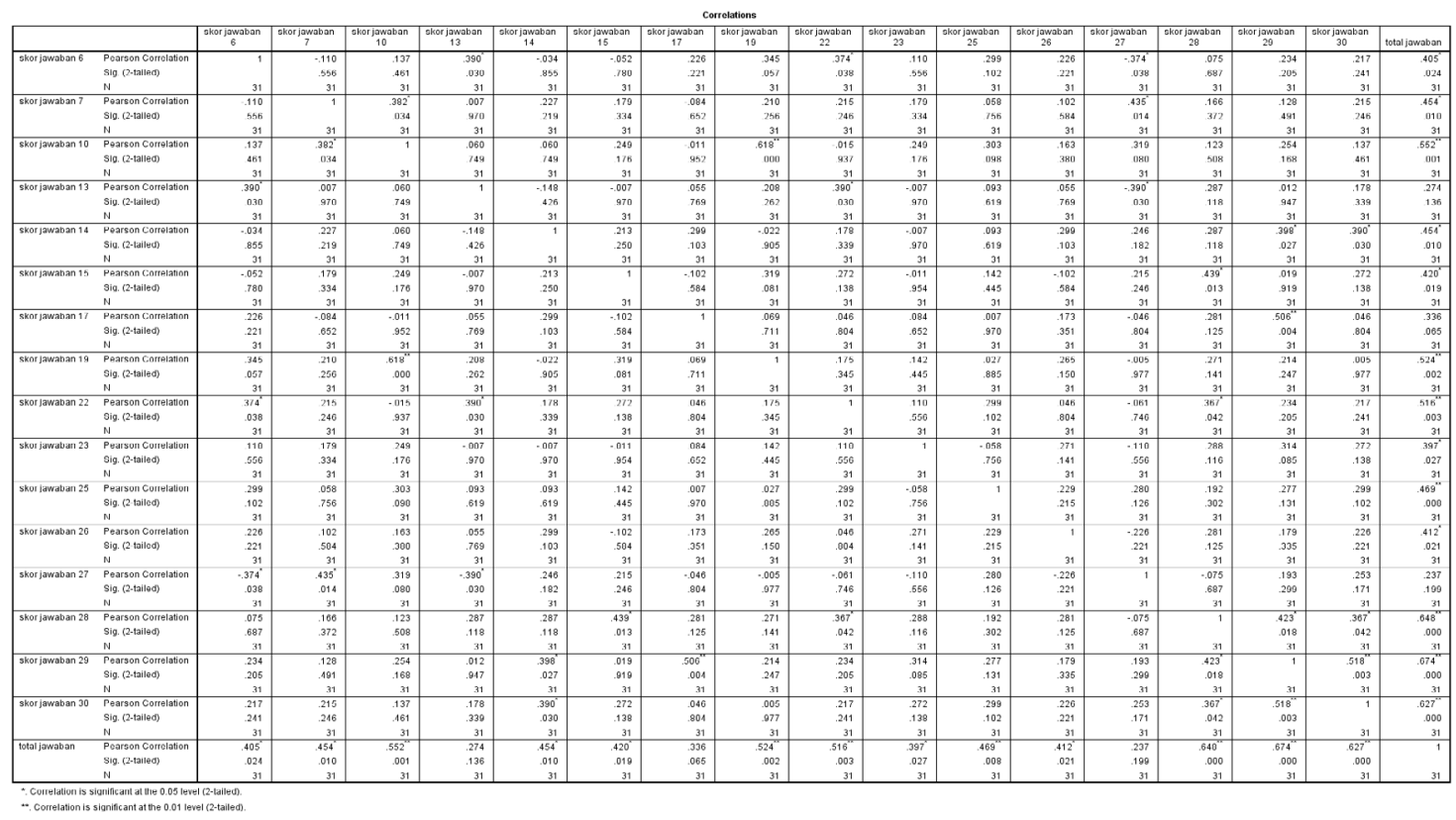

Gambar 2. Korelasi Product Moment Aspek Proses Pemahaman 
Taraf kevalidan tiap butir soal, diukur berdasarkan data tabel di atas, dengan: 31, Sehingga, nilai pada tabel product moment $=0,367$. Berdasarkan hasil analisis dengan bantuan IBM SPSS Statistics 22 didapat nilai untuk nomor 1, 2, 4, 9, 13, 17, 18, dan 27 kurang dari 0,367. Maka dapat disimpulkan bahwa nomor-nomor soal tersebut tidak valid.

Uji validitas tes dapat diukur dengan melihat korelasi skor butir soal (skor item) dengan skor total. Sehingga diperoleh 22 soal yang valid. Soal tersebut terdiri dari 3 soal untuk mengetahui membaca karya sastra dan ada 6 soal untuk mengetahui membaca untuk pemerolehan informasi. Kemudian pada soal yang berkaitan dengan proses membaca ada 14 soal. Terdiri dari 3 soal untuk mengetahui proses mencari dan menemukan informasi, 4 soal untuk mengetahui kesimpulan, 4 soal untuk mengetahui cara menafsirkan dan memadukan gagasan, dan 2 soal untuk mengetahui cara menilai konten dan penggunaan bahasa.

Tabel 1. Hasil Penelitian Aspek Literasi Tujuan Membaca Kelas IV A

SD Muhammadiyah Bantul Kota

\begin{tabular}{|c|c|c|c|c|c|c|c|c|c|c|c|c|c|c|c|}
\hline \multirow{3}{*}{ Sampel } & \multicolumn{9}{|c|}{ Aspek Tujuan Membaca } & \multicolumn{2}{|c|}{ Skor } & \multicolumn{2}{|c|}{ Persentase } & \multicolumn{2}{|c|}{ Kategori } \\
\hline & \multicolumn{3}{|c|}{ Sastra } & \multicolumn{6}{|c|}{ Informasi } & \multirow{2}{*}{ Sastra } & \multirow{2}{*}{ Informasi } & \multirow{2}{*}{ Sastra } & \multirow{2}{*}{ Informasi } & \multirow{2}{*}{ Sastra } & \multirow{2}{*}{ Informasi } \\
\hline & 3 & 5 & 8 & 11 & 12 & 16 & 20 & 21 & 24 & & & & & & \\
\hline 1 & 1 & 1 & 1 & 1 & 1 & 1 & 1 & 1 & 1 & 3 & 6 & 100 & 100 & A & A \\
\hline 2 & 1 & 1 & 1 & 1 & 1 & 1 & 1 & 1 & 0 & 3 & 5 & 100 & 83.33 & A & A \\
\hline 3 & 1 & 1 & 1 & 1 & 1 & 1 & 0 & 0 & 0 & 3 & 3 & 100 & 50 & $\mathrm{~A}$ & $\mathrm{D}$ \\
\hline 4 & 1 & 1 & 0 & 1 & 1 & 1 & 1 & 1 & 1 & 2 & 6 & 66.67 & 100 & B & A \\
\hline 5 & 1 & 1 & 1 & 0 & 1 & 1 & 1 & 1 & 0 & 3 & 4 & 100 & 66.67 & A & B \\
\hline 6 & 1 & 1 & 1 & 1 & 1 & 1 & 1 & 1 & 0 & 3 & 5 & 100 & 83.33 & A & A \\
\hline 7 & 0 & 0 & 0 & 0 & 0 & 0 & 0 & 1 & 0 & 0 & 1 & 0 & 16.67 & $\mathrm{E}$ & $\mathrm{E}$ \\
\hline 8 & 1 & 1 & 1 & 0 & 1 & 1 & 1 & 1 & 1 & 3 & 5 & 100 & 83.33 & A & A \\
\hline 9 & 1 & 1 & 1 & 0 & 1 & 1 & 1 & 1 & 0 & 3 & 4 & 100 & 66.67 & A & B \\
\hline 10 & 0 & 1 & 1 & 1 & 1 & 1 & 1 & 1 & 1 & 2 & 6 & 66.67 & 100 & B & A \\
\hline 11 & 1 & 1 & 1 & 1 & 1 & 1 & 1 & 1 & 1 & 3 & 6 & 100 & 100 & A & A \\
\hline 12 & 1 & 1 & 1 & 1 & 1 & 1 & 0 & 1 & 0 & 3 & 4 & 100 & 66.67 & A & B \\
\hline 13 & 1 & 1 & 1 & 1 & 1 & 1 & 1 & 1 & 1 & 3 & 6 & 100 & 100 & A & A \\
\hline 14 & 1 & 1 & 1 & 1 & 1 & 1 & 1 & 1 & 0 & 3 & 5 & 100 & 83.33 & A & A \\
\hline 15 & 1 & 1 & 1 & 0 & 1 & 1 & 0 & 1 & 0 & 3 & 3 & 100 & 50 & A & $\mathrm{D}$ \\
\hline
\end{tabular}


Tingkat Literasi Membaca Peserta Didik Kelas IV

\begin{tabular}{|c|c|c|c|c|c|c|c|c|c|c|c|c|c|c|c|}
\hline \multirow{3}{*}{ Sampel } & \multicolumn{9}{|c|}{ Aspek Tujuan Membaca } & \multicolumn{2}{|c|}{ Skor } & \multicolumn{2}{|c|}{ Persentase } & \multicolumn{2}{|c|}{ Kategori } \\
\hline & \multicolumn{3}{|c|}{ Sastra } & \multicolumn{6}{|c|}{ Informasi } & \multirow{2}{*}{ Sastra } & \multirow{2}{*}{ Informasi } & \multirow{2}{*}{ Sastra } & \multirow{2}{*}{ Informasi } & \multirow{2}{*}{ Sastra } & \multirow{2}{*}{ Informasi } \\
\hline & 3 & 5 & 8 & 11 & 12 & 16 & 20 & 21 & 24 & & & & & & \\
\hline 16 & 1 & 1 & 1 & 1 & 1 & 1 & 0 & 1 & 1 & 3 & 5 & 100 & 83.33 & A & A \\
\hline 17 & 1 & 1 & 1 & 1 & 1 & 1 & 1 & 1 & 0 & 3 & 5 & 100 & 83.33 & A & A \\
\hline 18 & 1 & 1 & 1 & 1 & 1 & 1 & 1 & 0 & 1 & 3 & 5 & 100 & 83.33 & $\mathrm{~A}$ & A \\
\hline 19 & 0 & 1 & 1 & 1 & 1 & 1 & 1 & 1 & 1 & 2 & 6 & 66.67 & 100 & B & A \\
\hline 20 & 0 & 1 & 1 & 1 & 1 & 1 & 1 & 0 & 0 & 2 & 4 & 66.67 & 66.67 & B & B \\
\hline 21 & 1 & 1 & 1 & 1 & 0 & 1 & 0 & 0 & 0 & 3 & 2 & 100 & 33.33 & A & $\mathrm{E}$ \\
\hline 22 & 0 & 1 & 1 & 0 & 0 & 1 & 0 & 0 & 0 & 2 & 1 & 66.67 & 16.67 & B & $\mathrm{E}$ \\
\hline 23 & 1 & 1 & 1 & 1 & 1 & 1 & 1 & 1 & 0 & 3 & 5 & 100 & 83.33 & A & A \\
\hline 24 & 0 & 1 & 1 & 0 & 0 & 0 & 1 & 0 & 0 & 2 & 1 & 66.67 & 16.67 & B & $\mathrm{E}$ \\
\hline 25 & 1 & 1 & 1 & 1 & 1 & 1 & 1 & 1 & 1 & 3 & 6 & 100 & 100 & A & A \\
\hline 26 & 1 & 1 & 0 & 0 & 0 & 0 & 0 & 0 & 0 & 2 & 0 & 66.67 & 0 & B & $\mathrm{E}$ \\
\hline 27 & 1 & 1 & 1 & 1 & 1 & 1 & 1 & 1 & 1 & 3 & 6 & 100 & 100 & A & A \\
\hline 28 & 1 & 1 & 1 & 1 & 1 & 0 & 1 & 0 & 1 & 3 & 4 & 100 & 66.67 & A & B \\
\hline 29 & 1 & 1 & 1 & 1 & 1 & 0 & 1 & 0 & 1 & 3 & 4 & 100 & 66.67 & A & B \\
\hline 30 & 1 & 1 & 1 & 1 & 1 & 1 & 1 & 1 & 1 & 3 & 6 & 100 & 100 & A & A \\
\hline 31 & 1 & 1 & 1 & 1 & 1 & 1 & 1 & 1 & 1 & 3 & 6 & 100 & 100 & A & A \\
\hline
\end{tabular}




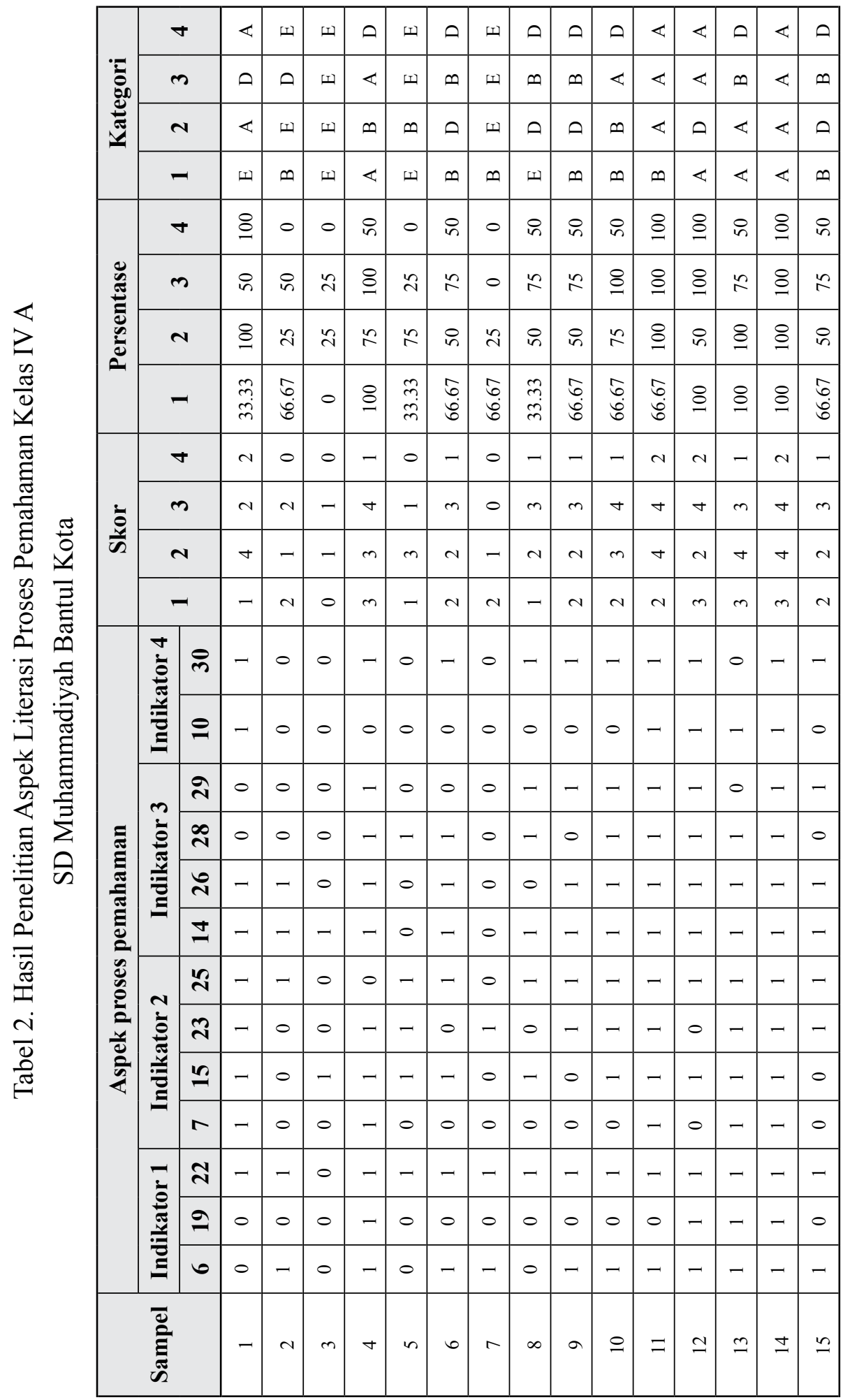




\begin{tabular}{|c|c|c|c|c|c|c|c|c|c|c|c|c|c|c|c|c|c|c|}
\hline \multirow{4}{*}{ 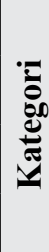 } & 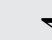 & $r$ & 0 & 0 & $\varangle$ & D & a & a & 디 & $\theta$ & Ш山 & D & 피 & $\theta$ & $\varangle$ & $\varangle$ & $\varangle$ & 0 \\
\hline & r & o & $\varangle$ & 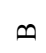 & 띠 & $\varangle$ & $\varangle$ & 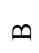 & D & 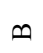 & D & 피 & 피 & $\varangle$ & O & $\varangle$ & $\varangle$ & $\varangle$ \\
\hline & & v & $\infty$ & 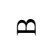 & 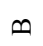 & 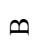 & D & D & 피 & 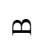 & $\theta$ & 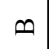 & $\amalg$ & $\varangle$ & 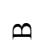 & $\infty$ & $\infty$ & 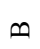 \\
\hline & & - & $\varangle$ & $\infty$ & $\infty$ & $\infty$ & 피 & 피 & 디 & 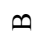 & 피 & $m$ & 디 & 띠 & 피 & 피 & $\varangle$ & $\infty$ \\
\hline \multirow{4}{*}{ 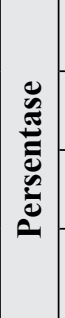 } & 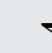 & $r$ & in & in & 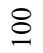 & in & in & in & 0 & in & 0 & in & 0 & in & 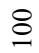 & $\nsubseteq$ & ¿ & in \\
\hline & o & o & 8 & $\approx$ & ֶิ & @ & $\nsubseteq$ & $\approx$ & in & 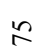 & in & 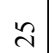 & ฉ & 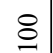 & in & 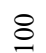 & $\nsubseteq$ & 8 \\
\hline & & v & $\approx$ & $\stackrel{n}{n}$ & 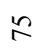 & $\approx$ & in & in & $\approx$ & $\stackrel{2}{2}$ & in & $\approx$ & $\approx$ & 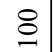 & $i$ & $\approx$ & $\approx$ & $\stackrel{n}{n}$ \\
\hline & & - & 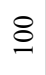 & $\begin{array}{l}\hat{6} \\
\dot{8}\end{array}$ & $\begin{array}{l}\hat{6} \\
\text { هें }\end{array}$ & $\begin{array}{l}\hat{6} \\
\stackrel{0}{0}\end{array}$ & $\stackrel{\text { ले }}{m}$ & 0 & 0 & $\begin{array}{l}\hat{6} \\
\dot{8}\end{array}$ & 0 & $\begin{array}{l}5 \\
0 \\
0\end{array}$ & $\underset{m}{m}$ & $\stackrel{m}{m}$ & $\stackrel{m}{m}$ & 0 & 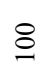 & $\begin{array}{l}\hat{6} \\
\dot{8}\end{array}$ \\
\hline \multirow{4}{*}{$\frac{\grave{o}}{\mathscr{a}}$} & & $r$ & - & - & $N$ & - & - & - & 0 & - & 0 & -1 & 0 & - & $N$ & $N$ & $N$ & - \\
\hline & & o & $\nabla$ & $m$ & - & ナ & ナ & $m$ & $\sim$ & $m$ & $N$ & - & - & $\sigma$ & $N$ & $\sigma$ & $\nabla$ & 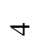 \\
\hline & & v & $m$ & $m$ & $m$ & $m$ & $N$ & $N$ & - & $m$ & $N$ & $m$ & - & 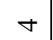 & $m$ & $m$ & $m$ & $m$ \\
\hline & & -1 & $m$ & $N$ & $N$ & 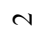 & - & 0 & 0 & $N$ & 0 & $N$ & - & - & - & 0 & $m$ & $N$ \\
\hline \multirow{13}{*}{ 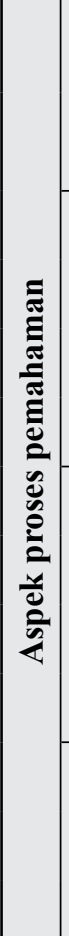 } & \multirow{2}{*}{ 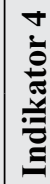 } & లి & 0 & - & - & - & - & - & 0 & - & 0 & - & 0 & - & - & - & - & - \\
\hline & & 으 & - & 0 & - & 0 & 0 & 0 & 0 & 0 & 0 & 0 & 0 & 0 & - & - & - & 0 \\
\hline & \multirow{4}{*}{ 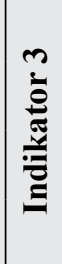 } & নे & - & 0 & 0 & - & - & 0 & 0 & 0 & 0 & 0 & 0 & - & - & - & - & - \\
\hline & & $\stackrel{\infty}{\sim}$ & - & - & 0 & - & - & - & 0 & - & 0 & 0 & 0 & - & 0 & - & - & - \\
\hline & & $\stackrel{\sim}{\sim}$ & - & - & - & - & - & - & - & - & - & 0 & - & - & 0 & - & - & - \\
\hline & & $\Xi$ & - & - & 0 & - & - & - & - & - & - & - & 0 & - & - & - & - & - \\
\hline & \multirow{4}{*}{ 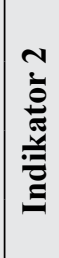 } & 㕮 & - & - & - & - & - & 0 & 0 & - & - & - & - & - & - & - & - & - \\
\hline & & $\ddot{\sim}$ & - & - & - & - & - & - & - & - & 0 & 0 & 0 & - & - & - & - & - \\
\hline & & $n$ & - & - & - & - & 0 & - & 0 & - & - & - & 0 & - & - & 0 & - & - \\
\hline & & $n$ & 0 & 0 & 0 & 0 & 0 & 0 & 0 & 0 & 0 & - & 0 & - & 0 & - & 0 & 0 \\
\hline & \multirow{3}{*}{ 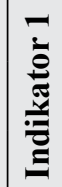 } & $\widetilde{N}$ & - & - & 0 & - & 0 & 0 & 0 & - & 0 & - & 0 & - & 0 & 0 & - & - \\
\hline & & $\underline{-}$ & - & 0 & - & 0 & 0 & 0 & 0 & 0 & 0 & 0 & 0 & 0 & 0 & 0 & - & 0 \\
\hline & & 6 & - & - & - & - & - & 0 & 0 & - & 0 & - & - & 0 & - & 0 & - & - \\
\hline & 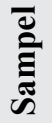 & & $\stackrel{0}{2}$ & I & $\stackrel{\infty}{\stackrel{1}{2}}$ & $\stackrel{2}{ }$ & ৯ & $\vec{v}$ & $\approx$ & $\tilde{\lambda}$ & $\stackrel{\Xi}{\sim}$ & $\approx$ & i & $\hat{\imath}$ & $\stackrel{\infty}{\sim}$ & নे & iे & $\bar{m}$ \\
\hline
\end{tabular}


Tabel 3. Hasil Akhir Penelitian Literasi Membaca Aspek Tujuan Membaca dan Proses Pemahaman Kelas IV A SD Muhammadiyah Bantul Kota

\begin{tabular}{|c|c|c|c|c|c|c|c|c|}
\hline \multirow{2}{*}{ Sampel } & \multicolumn{2}{|c|}{ Tujuan Membaca } & \multicolumn{4}{|c|}{ Proses Pemahaman } & \multirow{2}{*}{$\begin{array}{c}\text { Total } \\
\text { Persentase }\end{array}$} & \multirow{2}{*}{ Kategori } \\
\hline & 1 & 2 & 1 & 2 & 3 & 4 & & \\
\hline 1 & 100 & 100 & 33.33 & 100 & 50 & 100 & 80.56 & A \\
\hline 2 & 100 & 83.33 & 66.67 & 25 & 50 & 0 & 54.17 & $\mathrm{D}$ \\
\hline 3 & 100 & 50 & 0 & 25 & 25 & 0 & 33.33 & $\mathrm{E}$ \\
\hline 4 & 66.67 & 100 & 100 & 75 & 100 & 50 & 81.94 & $\mathrm{~A}$ \\
\hline 5 & 100 & 66.67 & 33.33 & 75 & 25 & 0 & 50.00 & $\mathrm{D}$ \\
\hline 6 & 100 & 83.33 & 66.67 & 50 & 75 & 50 & 70.83 & $\mathrm{~B}$ \\
\hline 7 & 0 & 16.67 & 66.67 & 25 & 0 & 0 & 18.06 & $\mathrm{E}$ \\
\hline 8 & 100 & 83.33 & 33.33 & 50 & 75 & 50 & 65.28 & $\mathrm{C}$ \\
\hline 9 & 100 & 66.67 & 66.67 & 50 & 75 & 50 & 68.06 & $\mathrm{~B}$ \\
\hline 10 & 66.67 & 100 & 66.67 & 75 & 100 & 50 & 76.39 & $\mathrm{~B}$ \\
\hline 11 & 100 & 100 & 66.67 & 100 & 100 & 100 & 94.44 & $\mathrm{~A}$ \\
\hline 12 & 100 & 66.67 & 100 & 50 & 100 & 100 & 86.11 & $\mathrm{~A}$ \\
\hline 13 & 100 & 100 & 100 & 100 & 75 & 50 & 87.50 & A \\
\hline 14 & 100 & 83.33 & 100 & 100 & 100 & 100 & 97.22 & $\mathrm{~A}$ \\
\hline 15 & 100 & 50 & 66.67 & 50 & 75 & 50 & 65.28 & $\mathrm{C}$ \\
\hline 16 & 100 & 83.33 & 100 & 75 & 100 & 50 & 84.72 & $\mathrm{~A}$ \\
\hline 17 & 100 & 83.33 & 66.67 & 75 & 75 & 50 & 75.00 & B \\
\hline 18 & 100 & 83.33 & 66.67 & 75 & 25 & 100 & 75.00 & B \\
\hline 19 & 66.67 & 100 & 66.67 & 75 & 100 & 50 & 76.39 & $\mathrm{~B}$ \\
\hline 20 & 66.67 & 66.67 & 33.33 & 50 & 100 & 50 & 61.11 & $\mathrm{C}$ \\
\hline 21 & 100 & 33.33 & 0 & 50 & 75 & 50 & 51.39 & $\mathrm{D}$ \\
\hline 22 & 66.67 & 16.67 & 0 & 25 & 50 & 0 & 26.39 & $\mathrm{E}$ \\
\hline 23 & 100 & 83.33 & 66.67 & 75 & 75 & 50 & 75.00 & B \\
\hline 24 & 66.67 & 16.67 & 0 & 50 & 50 & 0 & 30.56 & E \\
\hline 25 & 100 & 100 & 66.67 & 75 & 25 & 50 & 69.44 & $\mathrm{~B}$ \\
\hline 26 & 66.67 & 0.00 & 33.33 & 25 & 25 & 0 & 25.00 & $\mathrm{E}$ \\
\hline 27 & 100 & 100 & 33.33 & 100 & 100 & 50 & 80.56 & $\mathrm{~A}$ \\
\hline 28 & 100 & 66.67 & 33.33 & 75 & 50 & 100 & 70.83 & B \\
\hline 29 & 100 & 66.67 & 0 & 75 & 100 & 100 & 73.61 & $\mathrm{~B}$ \\
\hline 30 & 100 & 100 & 100 & 75 & 100 & 100 & 95.83 & A \\
\hline 31 & 100 & 100 & 66.67 & 75 & 100 & 50 & 81.94 & A \\
\hline
\end{tabular}

38 AL-BIDAYAH, Volume 10, Nomor 01, Juni 2018 
Dari hasil penelitian di atas diperoleh beberapa kategori literasi membaca berdasarkan persentase skor nilai benar dalam soal pada aspek tujuan membaca dan proses pemahaman. Kategori literasi membaca tersebut adalah sangat tinggi, tinggi, sedang, rendah dan sangat rendah. Untuk kelompok peserta didik dengan kategori sangat tinggi, terdapat 10 peserta didik dengan sampel nomor $1,4,11,12,13,14$, 16, 27, 30 dan 31. Untuk kelompok peserta didik dengan kategori tinggi terdapat 10 peserta didik dengan sampel nomor 6, 9, 10, 17, 18, 19, 23, 25, 28 dan 29. Untuk kelompok peserta didik dengan kategori sedang terdapat 3 peserta didik dengan sampel nomor 8, 15 dan 20. Untuk kelompok peserta didik dengan kategori rendah terdapat 3 peserta didik dengan sampel nomor 2, 5 dan 21. Untuk kelompok peserta didik dengan kategori sangat rendah terdapat 5 peserta didik dengan sampel nomor 3, 7, 22, 24 dan 26.

Dari hasil yang diperoleh peneliti, pada aspek tujuan membaca yang terdiri dari membaca karya sastra dan membaca untuk memperoleh informasi. Hasil analisis deskriptif persentase menunjukkan rata-rata pencapaian membaca untuk karya sastra adalah $89 \%$ dengan kategori A (sangat tinggi). Kemudian untuk rata-rata pencapaian membaca untuk memperoleh informasi adalah $73 \%$ dengan kategori B (sangat tinggi). Untuk rata-rata persentase dalam indikator tujuan membaca adalah $81 \%$ dengan kategori A (sangat tinggi).

Pada aspek proses pemahaman terdiri dari indikator proses mencari dan menemukan informasi, menarik kesimpulan, menafsirkan dan memadukan gagasan dan menilai konten dan penggunaan bahasa. Dari indikator proses mencari dan menemukan informasi diperoleh rata-rata persentase 55\% dengan kategori D (rendah), kemudian untuk indikator menarik kesimpulan diperoleh rata-rata persentase $65 \%$ dengan kategori C (sedang), selanjutnya untuk indikator menafsirkan dan memadukan gagasan diperoleh rata-rata persentase $70 \%$ dengan kategori B (tinggi), dan untuk indikator menilai konten dan penggunaan bahasa diperoleh rata-rata persentase $52 \%$ dengan kategori $\mathrm{D}$ (rendah). Rata-rata persentase dalam indikator proses pemahaman adalah $67 \%$ dengan kategori B yaitu tinggi.

Dengan demikian, diperoleh hasil bahwa dari 31 peserta didik, untuk aspek tujuan membaca dalam indikator membaca karya sastra terdapat 23 peserta didik yang memperoleh kategori A, 7 peserta didik yang memperoleh kategori B dan 1 peserta didik memperoleh kategori E. Sedangkan dalam indikator membaca untuk memperoleh informasi terdapat 18 peserta didikyang memperoleh kategori A, 6 peserta 
didik yang memperoleh kategori B, 2 peserta didik yang memperoleh kategori $\mathrm{D}$, dan 5 peserta didik memperoleh kategori E. Kemudian untuk aspek proses pemahaman dalam indikator proses mencari dan menemukan informasi terdapat 6 peserta didik yang memperoleh kategori $\mathrm{A}, 13$ peserta didik yang memperoleh kategori $\mathrm{B}$, dan 12 peserta didik yang memperoleh kategori E. Sedangkan dalam indikator menarik kesimpulan terdapat 5 peserta didik yang memperoleh kategori A, 13 peserta didik yang memperoleh kategori $\mathrm{B}, 8$ peserta didik yang memperoleh kategori $\mathrm{D}$ dan 5 peserta didik memperoleh kategori E. sedangkan dalam indikator menafsirkan dan memadukan gagasan terdapat 12 peserta didik yang memperoleh kategori A, 8 peserta didik yang memperoleh kategori B, 5 peserta didik yang memperoleh kategori D dan 6 peserta didik memperoleh kategori E. Sedangkan indikator menilai konten dan penggunaan bahasa terdapat 8 peserta didik yang memperoleh kategori, 16 peserta didik yang memperoleh kategori D dan 7 peserta didik yang memperoleh kategori $\mathrm{E}$.

Untuk instrumen angket yang diisi oleh 31 peserta didik yang terdiri dari 45,16\% (14 perempuan) dan 58,84\% (17 laki-laki). Dari keseluruhan peserta didik terdiri dari $77,42 \%$ (24 peserta didik) berumur 11 tahun dan 22,58\% (7 peserta didik) berumur 10 tahun. Dalam kegiatan membaca buku di rumah, untuk persentase tertinggi yaitu 48,39\% (15 peserta didik) menyatakan membaca buku hanya 1 sampai 2 kali seminggu. Kemudian 41, 95\% (13 peserta didik) yang menyatakan selalu membaca buku setiap hari di rumah. Sisanya 9,68 (3 peserta didik) menyatakan membaca buku satu bulan sekali.

Kegemaran peserta didik dalam membaca dilihat dari kepemilikan buku yang dimiliki di rumah, untuk persentase tertinggi sebanyak 45,16\% (14 peserta didik) memiliki buku yang sangat sedikit atau kurang dari 10 buku. Terdapat 32,26\% (10 peserta didik) memiliki buku sebanyak 11-25 yang cukup untuk mengisi setengah rak buku. Terdapat 16,13\% (5 peserta didik) memiliki buku sebanyak 26-100 buku yag cukup untuk mengisi satu rak buku. Sisanya $6,45 \%$ (2 peserta didik) memilki buku sebanyak lebih dari 100 buku yang cukup untuk mengisi dua rak buku.

Selain buku setiap peserta didik memilki benda-benda pribadi yang mendukung adanya literasi membaca. Berdasarkan jawaban peserta didik mengenai kepemilikan benda pribadinya diketahui 41,94\% (13 peserta didik) memilki komputer di rumah dan sisanya tidak memiliki komputer. Untuk kepemilikan meja belajar terdapat 93,55 (29 peserta didik) memiliki meja belajar sendiri yang digunakan untuk belajar dan sisanya tidak memiliki meja belajar sendiri. Untuk kepemilikan buku bacaan sendiri 
di rumah terdapat $96,77 \%$ (30 peserta didik) memiliki buku bacaan milik sendiri untuk koleksinya di rumah dan sisanya tidak memiliki. Untuk kepemilikan koneksi internet terdapat 51,61\% (16 peserta didik) memiliki koneksi jaringan internet di rumahnya dan sisanya tidak memiliki. Kemudian untuk kepemilikan surat kabar terdapat $32,26 \%$ (10 peserta didik) memilki surat kabar di rumahnya dan sisanya tidak memiliki.

Pendidikan orang tua peserta didik juga mempengaruhi adanya literasi membaca di rumah. Berdasarkan jawaban peserta didik ada persentase tertinggi yaitu 70,97 (22 peserta didik) menyatakan bahwa pendidikan terakhir orang tuanya adalah di universitas. Terdapat $25,81 \%$ ( 8 peserta didik) yang menyatakan bahwa pendidikan terakhir orang tuanya di SMA dan sisanya 3,23\% (1 peserta didik) yang menyatakan bahwa pendidikan terakhir orang tuanya adalah di SMP.

Hasil perhitungan indikator kebiasaan peserta didik bersama orang tuanya di rumah yaitu terdiri 6 sub indikator. Pada hasil sub indikator 1 yaitu orang tua menemani membaca buku dengan persentase tertinggi 77,42\% (24 peserta didik) memberikan jawaban kadang-kadang. Terdapat 12,90\% (4 peserta didik) memberikan jawaban tidak pernah dan sisanya 9,68\% (3 peserta didik) menyatakan bahwa sering ditemani orang tuanya ketika membaca buku.

Pada sub indikator 2 yaitu orang tua bercerita menggunakan buku bacaan dengan persentase tertinggi 54,84\% (17 peserta didik) memberikan jawaban tidak pernah. Terdapat 38,71\% (12 peserta didik) memberikan jawaban kadang-kadang dan sisanya 6,45 ( 2 peserta didik) menyatakan sering ditemani orang tuanya bercerita dengan menggunakan buku bacaan.

Pada sub indikator 3 yaitu orang tua mengajak bernyanyi dengan persentase tertinggi 48,39\% (15 peserta didik) memberikan jawaban kadang-kadang. Terdapat 41,94\% (13 peserta didik) memberikan jawaban tidak pernah dan sisanya 9,68 (3 peserta didik) memberikan jawaban sering diajak orang tuanya bernyanyi.

Pada sub indikator 4 yaitu orang tua mengajak bermain dengan menggunakan huruf dengan persentase tertinggi 61,29\% (19 peserta didik) memberikan jawaban tidak pernah. Terdapat 29, 03 (9 peserta didik) memberikan jawaban kadang-kadang dan sisanya 9,68 (3 peserta didik) memberikan jawaban sering diajak orang tuanya dalam melakukan permainan dengan menggunakan huruf.

Pada sub indikator 5 yaitu orang tua mengajak bermain dengan menggunakan kata dengan persentase tertinggi 51,61\% (16 peserta didik) menyatakan bahwa kadang- 
kadang. Terdapat 32,26\% (10 peserta didik) memberikan jawaban tidak pernah dan sisanya $16,13 \%$ (5 peserta didik) memberikan jawaban sering diajak orang tuanya dalam melakukan permainan dengan menggunakan kata.

Pada sub indikator 6 yaitu orang tua mendengarkan ketika peserta didik membaca nyaring dengan persentase tertinggi 48,39\% (15 peserta didik) menyatakan bahwa kadang-kadang. Terdapat 32,26\% (10 peserta didik) memberikan jawaban sering dan sisanya 19,35 (6 peserta didik) memberikan jawaban orang tuanya tidak pernah mendengarkannya ketika membaca dengan nyaring.

Berdasarkan perhitungan indikator peserta didik tentang pendapatnya dalam membaca yang terdiri dari 5 sub indikator. Sub indikator 1 yaitu membaca hanya jika ingin dengan persentase tertinggi 51,61\% (16 peserta didik) memberikan jawaban cukup setuju. Terdapat ada 22,58\% (7 peserta didik) memberikan jawaban sangat setuju; 19, 35\% (6 peserta didik) memberikan jawaban tidak setuju dan sisanya 6,45\% (2 peserta didik) memberikan jawaban sangat tidak setuju jika membaca hanya jika ingi saja.

Pada sub indikator 2 yaitu membicarakan buku yang telah dibaca dengan orang lain dengan persentase tertinggi 51,61\% (16 peserta didik) memberikan jawaban sangat setuju. Terdapat 41,94\% (13 peserta didik) memberikan jawaban cukup setuju dan sisanya $6,45 \%$ ( 2 peserta didik) memberikan jawaban tidak setuju bahwa ia suka membicarakan buku yang telah dibaca dengan orang lain. Pada sub indikator 3 yaitu senang apabila diberikan hadiah buku dengan persentase tertinggi 70,97\% (22 peserta didik) memberikan jawaban sangat setuju dan sisanya 29,03\% (9 peserta didik) memeberikan jawaban cukup setuju.

Pada sub indikator 4 yaitu membaca adalah hal yang membosankan dengan persentase tertinggi 41,94\% (13 peserta didik) memberikan jawaban tidak setuju. Terdapat $35,48 \%$ (11 peserta didik) memberikan jawaban sangat tidak setuju; $16,13 \%$ (5 peserta didik) memberikan jawaban cukup setuju dan sisanya 6,45\% (2 peserta didik) memberikan jawaban sangat setuju apabila membaca adalah hal yang membosankan. Pada sub indikator 5 yaitu adanya perasaan senang ketika membaca dengan persentase tertinggi 54,84\%(17 peserta didik) memberikan jawaban sangat setuju. Terdapat 38,71\% (12 peserta didik) memberikan jawaban cukup setuju dan sisanya $6,45 \%$ ( 2 peserta didik) memberikan jawaban tidak setuju.

Berdasarkan perhitungan indikator seberapa hasil baik peserta didik dalam membaca yang terdiri dari 7 sub indikator. Pada sub indikator 1 yaitu peserta 
didik merasa bisa membaca dengan baik dengan persentase tertinggi 80,65\% (25 peserta didik) memberikan jawaban sangat setuju dan sisanya 19,35\% (6 peserta didik) menyatakan cukup setuju. Pada sub indikator 2 yaitu peserta didik merasa membaca adalah hal yang mudah dengan persentase tertinggi 70,97\% (22 peserta didik) memberikan jawaban sangat setuju dan sisanya 29,03\% ( 9 peserta didik) memberikan jawaban cukup setuju. Pada sub indikator 3 yaitu membaca adalah hal yang sulit daripada beberapa teman sekelas dengan persentase tertinggi 54,84\% (17 peserta didik) memberikan jawaban tidak setuju. Terdapat 36,71\% (12 peserta didik) memberikan jawaban sangat setuju dan untuk jawaban sangat setuju dan cukup setuju memperoleh persentase yang sama yaitu 3,23\% (1 peserta didik).

Pada sub indikator 4 yaitu jika buku itu menarik maka tidak peduli seberapa sulit untuk dibaca dengan persentase tertinggi 51,61\% (16 peserta didik) memberikan jawaban sangat setuju. Terdapat 25,81\% (8 peserta didik) memberikan jawaban cukup setuju; $19,35 \%$ ( 6 peserta didik) memberikan jawaban tidak setuju dan sisanya $3,23 \%$ (1 peserta didik) memberikan jawaban sangat tidak setuju. Pada sub indikator 5 yaitu peserta didik memiliki masalah dalam membaca kata-kata sulit dengan persentase tertinggi 38,71\% (12 peserta didik) memberikan jawaban setuju. Terdapat $25,58 \%$ ( 8 peserta didik) memberikan jawaban tidak setuju; $22,58 \%$ ( 7 peserta didik) memberikan jawaban sangat tidak setuju dan sisanya 12,90\% (4 peserta didik) memberikan jawaban sangat setuju.

Pada sub indikator 6 yaitu membaca merupakan hal yang sulit dengan persentase tertinggi 58,06\% (18 peserta didik) memberikan jawaban sangat tidak setuju. Terdapat $35,48 \%$ (11 peserta didik) memberikan jawaban tidak setuju dan sisanya untuk jawaban sangat setuju dan cukup setuju memperoleh persentase yang sama yaitu $3,23 \%$ ( 1 peserta didik). Pada sub indikator 7 yaitu guru memberitahu bahwa peserta didik adalah pembaca yang baik dengan persentase tertinggi 64,52\% (20 peserta didik) memberikan jawaban sangat setuju. Terdapat 32,26\% (10 peserta didik) memberikan jawaban cukup setuju dan sisanya 3,23\% (1 peserta didik) memberikan jawaban tidak setuju.

Ada beberapa faktor yang mempengaruhi kemampuan membaca peserta didik kelas IV salah satunya adalah kebiasaan dan sikap membaca. Dalam kebiasaan membaca buku, paling banyak peserta didik membaca buku 1 sampai 2 kali seminggu. Buku bacaan yang dimiliki peserta didik paling banyak 11-25 buku. Kebersamaan dengan orang tua di rumah dalam melaksanakan kegiatan literasi membaca juga 
menjadi faktor utama. Dilihat dari pendidikan orang tua peserta didik juga mendukung adanya literasi membaca yang tinggi karena sebanyak 22 peserta didik pendidikan orang tuanya adalah universitas. Selain itu beberapa kepemilikan benda-benda pribadi yang dapat meningkatkan literasi membaca itu sendiri. Kemudian guru juga sudah berusaha memberitahu peserta didik bahwa ia adalah pembaca yang baik, sehingga dapat menumbuhkan motivasi untuk lebih sering lagi dalam membaca buku.

\section{KESIMPULAN}

Berdasarkan analisis data penelitian ini diperoleh hasil bahwa tingkat literasi membaca di SD Muhammadiyah Bantul Kota, khusus kelas IV A, dari aspek tujuan membaca dan proses pemahaman terbagi menjadi 5 kategori, yaitu terdapat 10 peserta didik yang memperoleh kategori sangat tinggi (A), 10 peserta didik dengan kategori tinggi (B), 3 peserta didik dengan kategori sedang (C), 3 peserta didik dengan kategori rendah (D), dan 5 peserta didik dengan kategori sangat rendah (E). Kemudian ratarata persentasenya mencapai $67 \%$ dengan kategori tinggi (B). Ada beberapa faktor yang mempengaruhi tinggi rendahnya literasi membaca peserta didik yaitu intensitas membaca buku, kepemilikan benda-benda yang mendukung kebiasaan membaca seperti buku dan komputer, pendidikan orang tua, kebiasaan membaca peserta didik bersama orang tua di rumah dan anggapan peserta didik dalam membaca.

\section{E. DAFTAR PUSTAKA}

Admin MEPNews. "Bantul Cerdas, Tapi Minat Baca Minim.” MEPNEWS.ID, 9 Maret 2017. http://mepnews.id/2017/03/09/bantul-cerdas-tapi-minat-baca$\operatorname{minim} /$.

Aminah (Ed.), Andi Nur. "Literasi Indonesia Sangat Rendah." Republika Online, 15 Desember 2014. https://republika.co.id/berita/koran/didaktika/14/12/15/ ngm3g840-literasi-indonesia-sangat-rendah.

Gewati, Mikhael. "Minat Baca Indonesia Ada di Urutan ke-60 Dunia." KOMPAS.com, 29 Agustus 2016. https://edukasi.kompas.com/read/2016/08/29/07175131/ minat.baca.indonesia.ada.di.urutan.ke-60.dunia.

Jurnalis Okezone. "Pelajar di DIY Memiliki Minat Baca Tinggi: Okezone News." https://news.okezone.com/. Diakses 1 Agustus 2018. https://news.okezone. $\mathrm{com} / \mathrm{read} / 2016 / 09 / 03 / 65 / 1480357 /$ pelajar-di-diy-memiliki-minat-bacatinggi. 
Wahyuni, Sri. "MENUMBUHKEMBANGKAN MINAT BACA MENUJU MASYARAKAT LITERAT." Diksi 16, no. 2 (2009). https://journal.uny.ac.id/ index.php/diksi/article/view/6617.

Widayanti, Wahyu. Wawancara dengan Pustakawan di Ruang Perpustakaan SD Muhammadiyah Bantul Kota, Agustus 2017. 
